\title{
Crop Diversification for Improved Weed Management: A Review
}

\author{
Gourav Sharma ${ }^{1}$, Swati Shrestha ${ }^{2}$, Sudip Kunwar ${ }^{2}$ and Te-Ming Tseng ${ }^{3, *}$ (i) \\ 1 School of Plant and Environmental Sciences, Virginia Tech, Blacksburg, VA 24061, USA; gourav1@vt.edu \\ 2 Department of Horticultural Sciences, University of Florida, Gainesville, FL 32611, USA; \\ s.shrestha@ufl.edu (S.S.); skunwar@ufl.edu (S.K.) \\ 3 Department of Plant and Soil Sciences, Mississippi State University, Starkville, MS 39762, USA \\ * Correspondence: t.tseng@msstate.edu
}

Citation: Sharma, G.; Shrestha, S.; Kunwar, S.; Tseng, T.-M. Crop Diversification for Improved Weed Management: A Review. Agriculture 2021, 11, 461. https://doi.org/ 10.3390/agriculture11050461

Academic Editor: Bärbel Gerowitt

Received: 12 April 2021

Accepted: 11 May 2021

Published: 19 May 2021

Publisher's Note: MDPI stays neutral with regard to jurisdictional claims in published maps and institutional affiliations.

Copyright: (c) 2021 by the authors. Licensee MDPI, Basel, Switzerland. This article is an open access article distributed under the terms and conditions of the Creative Commons Attribution (CC BY) license (https:// creativecommons.org/licenses/by/ $4.0 /)$.

\begin{abstract}
Weeds are among the major constraints to any crop production system, reducing productivity and profitability. Herbicides are among the most effective methods to control weeds, and reliance on herbicides for weed control has increased significantly with the advent of herbicideresistant crops. Unfortunately, over-reliance on herbicides leads to environmental-health issues and herbicide-resistant weeds, causing human health and ecological concerns. Crop diversification can help manage weeds sustainably in major crop production systems. It acts as an organizing principle under which technological innovations and ecological insights can be combined to manage weeds sustainably. Diversified cropping can be defined as the conscious inclusion of functional biodiversity at temporal and/or spatial levels to improve the productivity and stability of ecosystem services. Crop diversification helps to reduce weed density by negatively impacting weed seed germination and weed growth. Additionally, diversified farming systems are more resilient to climate change than monoculture systems and provide better crop yield. However, there are a few challenges to adopting a diversified cropping system, ranging from technology innovations, government policies, farm-level decisions, climate change, and market conditions. In this review, we discuss how crop diversification supports sustainable weed management, the challenges associated with it, and the future of weed management with respect to the diversification concept.
\end{abstract}

Keywords: herbicide resistance; crop diversification; intercropping; crop rotation; cover crops; sustainable; weeds; climate change

\section{Introduction}

Weeds can be defined as any plant that is objectionable or interferes with the activities or welfare of humans [1]. In a crop production system, weeds compete for the same resources as the crops, such as water, nutrients, sunlight, and space, limiting crop productivity [2]. Aggressive weed competition reduces crop yield significantly and adds further cost to crop production owing to their management [3]. Yield loss due to weeds depends on several factors such as density, time of emergence, type of weed, and crop type $[4,5]$. Globally, up to $40 \%$ yield loss because of weeds has been reported [6]. In the USA, yield loss because of weeds has been estimated to exceed eight dollar billion annually [7]. Among US crops, corn and soybean suffer the highest aggregate production loss because of weeds. On average, across 2007-2013, weed interference caused 52 and 50\% yield loss in soybean and corn, respectively, in the USA and Canada [8,9]. In Australia and India, annual yield losses due to weeds in grain crops were estimated to be 2.52 and 11 billion USD, respectively $[10,11]$. China reported a grain loss of approximately 3 million metric tons each year because of weeds [12]. These data indicate that weeds continue to be a major threat in crop production, causing substantial economic and yield loss worldwide [13].

In developing countries, subsistence farming is the primary form of agriculture, and weeds are generally managed through hand-weeding. However, due to increasing urbanization, increased labor costs, and decreasing workforce in agriculture, people are moving 
towards using chemicals for controlling weeds. In Southeast Asian countries such as Nepal, Bhutan, Bangladesh, and Thailand, there has been an increase in the haphazard use of herbicides for weed control in subsistence farming systems leading to health and environmental concerns $[14,15]$. In developed countries such as the USA, China, and Brazil, farmers are engaged in specialized agricultural production systems with the increased use of synthetic fertilizers and herbicides. The top ten consumers of pesticides globally are China, USA, Argentina, Thailand, Brazil, Italy, France, Canada, Japan, and India [16]. In 2014, approximately 2 million tons of chemical pesticides were used in the agricultural sector globally, of which $47.5 \%$ constituted herbicides [17]. Over-reliance on herbicides to control weeds and injudicious use of herbicides has led to several issues such as herbicide-resistant weeds, herbicide drift, environmental and health problems, and extinction or population reduction of segetal species [18-20]. Currently, there are approximately 500 unique cases of herbicide-resistant weeds globally [18]. Among the global herbicide-resistant weed cases, most were reported in the USA, followed by Australia, Canada, China, and Brazil [18]. In addition to this, some weeds have developed resistance to multiple modes of action while others have (developed decreased sensitivity to herbicides [21-23]. Both target-site and non-target-site mutations in the herbicide-resistant weeds have been reported [24,25]. These observations indicate over-reliance on herbicides as a non-sustainable measure for weed control. The development of herbicides with novel modes of action is imperative for herbicide resistance management; however, no new mode of action has been developed in the past three decades [26].

Further, there have been increasing reports of crop damage because of herbicide drift in recent years. For instance, 2,4-dichlorophenoxyacetic acid (2,4-D) is one of the most used herbicides to control broadleaf weeds in agriculture; however, they often damage the neighboring 2,4-D sensitive cotton field resulting in the loss of millions of dollars in the USA and Australia [27]. Likewise, severe crop injury has been reported due to the off-target movement of dicamba to the neighboring fields with non-dicamba tolerant crops [28,29]. Further, increasing use of herbicides has led to the accumulation of agricultural contaminants such as arsenic, cadmium, lead, and mercury in soil and water resources [30]. In the USA, a survey of 51 major river basins by the US Geological Survey reported that pesticides were detected in $97 \%$ of the samples from streams near agricultural areas [31]. Short and long-term health effects from exposure to agricultural chemicals have also been documented [32,33]. These examples provide evidence that over-dependence on herbicides may result in the increased frequency of herbicide resistance in weeds, water and soil pollution, and herbicide drift. Thus, to mitigate and/or eradicate ecological, environmental, and social externalities associated with intensive use of herbicides, it is imperative to design and promote alternative weed management approaches.

Studies have suggested that increasing crop diversity can subject weeds to a greater number of stresses and reduce reliance on external chemicals for weed/pest control [34,35]. Crop diversification can be defined as the conscious inclusion of functional biodiversity at the temporal and/or spatial levels to improve productivity and stability of ecosystem services [36]. The concept of crop diversification is complex, and a diversified cropping system is more complicated with different crop combinations, unlike monoculture, where extensive farmlands are cultivated with one or two annual crops. Modern agricultural practices have simplified the agricultural systems to enhance the profitability of major crops or livestock. In contrast, a diversified cropping system focuses on creating sustainable, resilient, and socially just global food systems. Some of the examples of a diversified cropping system would be (i) multiple genotypes of the same crop or different crops grown in polyculture [36], (ii) inclusion of legumes in otherwise cereal dominated systems [36] and, (iii) temporal and spatial rotation of crops, including but not limited to cover crops, trap crops, hedgerows, fallow fields, etc. [36]

There are certain set of rules on which crops to choose in a diversified farming system (for, e.g., Liebman and Dyck talks about strategies for crop rotation and intercropping in context of weed management [37]). The consequences of diversification include, but are 
not limited to, increased soil nutrient recycling, pest and disease suppression, enhanced water use efficiency, and pollination [38]. Many of the previous studies have advocated the importance of crop diversification in sustainable agricultural production $[39,40]$. However, knowledge of how different crop diversification techniques impact weed management and the constraints of adopting crop diversification in the modern agricultural context is lacking [41]. This review paper will discuss various crop diversification techniques in terms of weed management and how crop diversification fits in today's era of modern agriculture. The knowledge will provide insights into how crop diversification can be integrated with the present agricultural system for sustainable weed management.

\section{Crop Diversification Focused on Weed Management}

Liebman and Staver [34] noted two general principles for weed management through crop diversification, (a) weeds should be subjected to various stress and mortality factors by using crop sequences containing different species and management practices, and (b) diversification methods should be designed to maximize the capture of light, nutrients, and water by crop, thus reducing the loss by weeds. These principles should be the foundation for any crop diversification methods (e.g., crop rotation, cover cropping, and intercropping). However, the objective of the diversification strategies is not to eliminate all the weeds, instead to control them. Weeds offer various ecosystem services, which sometimes are beneficial to crops and humans [42-47].

\subsection{Crop Rotation}

Crop rotation is the practice of growing a series of crops sequentially over time on the same land, thus providing temporal variability [48]. Crop rotation is a sustainable agricultural practice aimed at achieving high economic output with minimum possible cost [49]. Zhao et al. [50] recently performed a meta-analysis on 45 studies and reported a $20 \%$ increment in crop yields due to crop rotation. Moreover, another meta-analysis on 54 studies showed that crop rotation leads to a $49 \%$ reduction in weed density [51]. Thus, crop rotation helps to reduce weed pressure and increase crop yield.

Weed species in monoculture tend to adapt to management practices and cause yield reductions (e.g., herbicide resistance, early seed shattering, and crop mimicry). In crop rotations, weeds are subjected to diverse weed control methods (no-tillage/till or diverse herbicides, planting dates, fertilization regime), thus preventing weeds from adapting and surviving [52]. Crop rotation diversifies the selection pressures on weeds by using alternative management tactics, alternating patterns, and timings of soil disturbance, light transmission, and nutrients. Therefore, crop rotation favors the establishment of diverse weed flora rather than dominated by one or few weed species, which in some cases leads to reduced input costs (e.g., herbicide usage) [53,54]. For example, Satorre et al. [55] reported modified weed communities and changed the frequency of some weed populations within the 31 soybean (Glycine max L.) fields in Argentina, which rotated with either corn (Zea mays L.) or wheat (Triticum aestivum L.).

Additionally, crop rotation negatively affects weed abundance, biomass, and density. For instance, corn-soybean-winter wheat rotation in Serbia reduces the number of weed species and biomass compared to continuous corn (CC). Moreover, it increases the yield by $30 \%$ compared to CC [56]. Similarly, rice-winter corn rotation suppressed $75 \%$ higher weed growth and resulted in $11 \%$ higher dry biomass than traditional rice-wheat rotation in India [57]. Unlike herbicides, change in weed community, and density takes time, and it is essential to look at the long-term effect. Simic et al. [56] reported corn, when rotated with winter wheat, causes a $92 \%$ reduction of weed biomass. This experiment was performed continuously for 11-year along with corn-soybean (CS) rotation. However, it is not always possible to conduct years-long research trials. In that case, modeling simulations are used, which will consider all growth and environmental parameters. For example, Liebman and Nicholas [58] modeled giant ragweed (Ambrosia trifida L.) population dynamics in different crop rotation scenarios. They predicted that to prevent an increase in giant 
ragweed density, the minimum control efficacy needed from herbicides or cultivation used in corn and soybean would be $99 \%$ in a 2 -year corn-soybean, whereas $91 \%$ in a 5 -year corn-soybean-rye-alfalfa system. Thus, diversified rotations have a higher probability of controlling giant ragweed populations. Several other models can help decide the crop rotations based on the need and geography [59-62].

Soil weed seedbanks preserve propagules for the next generation with the traits such as genetic diversity, long-term seed dormancy, erratic germination, and herbicide resistance/susceptibility [63]. These traits allow weeds to thrive in diverse conditions, including stress from management practices and harsh environments. Crop rotation is one of the various approaches to manage soil seedbanks. For instance, Anderson et al. [64] showed that crop rotations could help reduce the seedbank of annual weeds by balancing the seed production frequency. Anderson [65] reported that weed density could be reduced by utilizing balanced life-cycle intervals in crop rotation design. For example, a 2-year interval rotation of warm-season crops diversifying with different planting dates (e.g., corn to sunflower (Helianthus spp. L.)) will increase the diversity of weeds and reduce the viability of weed seeds in the soil seedbank [66,67]. The most advantageous rotation sequences for weed seed management should include four different crops in a series of two warm-season crops followed by cool-season crops [64]. This strategy will help eliminate seed production of warm-season weeds during the two-year cool-season crop and will further decrease during next year's crop [66]. Additionally, crop rotation can help reduce the seedbank density and composition (e.g., Cardina et al. [68] in CC, CS, and corn-oats-hay rotation and Westerman et al. [69] in CS and CS-triticale+ alfalfa-alfalfa).

Crop rotation with a non-host of parasitic plants can help reduce the seedbank of parasitic weeds. The non-host crop is also known as a trap crop, which tricks parasitic seeds to germinate while not causing any crop loss. Oswald and Ransom [70] reported crop rotation as one of the most effective methods to reduce Striga infestations in corn and increase corn yields. Samake et al. [71] concluded similar results for Striga hermonthica L. in traditional millet and cowpea rotation. Parasitic weeds are genetically diverse and can have differential germination responses to natural stimuli. For example, Hayat et al. [72] showed that the germination of broomrape species (Orobanche cumana Wallr and Phelipanche aegyptiaca Pers.) responds differently to 2-year crop rotation of sugar beet, pepper, and wheat with sunflower and tomato. O. cumana seedbank was reduced after two years, whereas there was no change in the seedbank of P. aegyptiaca, thus, making them difficult to manage with the same crop rotation. Crop rotation can also help prevent herbicide resistance by promoting the usage of herbicides with diverse modes of action. Norsworthy et al. [73] listed crop rotation as one of the best management practices to mitigate herbicide resistance. Herbicide-resistant risk is greater where no crop rotation is practiced as compared to fields with crop rotation. For example, modeling simulations have been shown to reduce glyphosate resistance in Palmer amaranth by two-fold if glyphosate-tolerant (GR) cotton is rotated with GR corn [74]. Similarly, blackgrass (Alopecurus myosuroides L.) is one of the most essential grass weeds of winter cereal crops in the UK and Europe. Over-reliance on chemical control has led to the widespread development of herbicide resistance in blackgrass. Crop rotation with spring cropping is one of the most effective methods of sustainable blackgrass control in the agricultural system (Table 1) [75]. Balanced crop rotation with spring cropping can reduce the blackgrass population by $78-96 \%$ [76]. Reduced blackgrass population in spring cropping is primarily because approximately $80 \%$ of the blackgrass germinates in autumn, and thus spring-sown crops are much less infected by blackgrass [75]. Thus, understanding the ecology of weeds and adapting to cultural practices can promote sustainable weed management with less dependency on herbicides.

A survey in Germany indicated that $89 \%$ of the farmers use crop rotation to control or prevent herbicide resistance [77]. Similarly, a Canadian farmer's survey in 2015 reported that $80 \%$ of the farmers depend on crop rotation to control herbicide resistance in the fields. Canola (Brassica napus L.) farmers in Canada use wheat as a rotation crop to gain profit and control ALS enzyme-inhibiting herbicide-resistant weeds [78]. In some cases, crop rotations 
can be highly profitable for the farmers. For instance, Goplen et al. [79] showed the average net return of alfalfa-alfalfa-corn (AAC) rotation in herbicide-resistant giant ragweed to be USD $919 \mathrm{ha}^{-1} \mathrm{yr}^{-1}$, whereas for CC to be USD $247 \mathrm{ha}^{-1} \mathrm{yr}^{-1}$. Moreover, AAC rotations for multiple years led to depleting the herbicide-resistant giant ragweed seedbank [80]. Overall, crop rotation can reduce the risk of herbicide resistance by diversifying weed flora and reducing seedbank.

\subsection{Intercropping}

Intercropping is an integrated weed management practice in which two or more crop species or genotypes are cultivated together and coexisting for a time. It is commonly used in countries with low-input (high-labor) and resource-limited agricultural systems on a small piece of land [81,82]. Intercrops can broadly be divided into three types: (a) relay intercropping (planting a second crop before the first crop is mature), (b) mixed intercropping (simultaneously growing two or more crops), and (c) strip cropping (growing two or more crops simultaneously in strips) Figure 1 [83]. Each type has its benefits, but overall intercropping compared with monocrops provides a similar yield with reduced inputs, pest control (weeds, diseases, and insects), and stable aggregate food yields per unit area $[84,85]$.

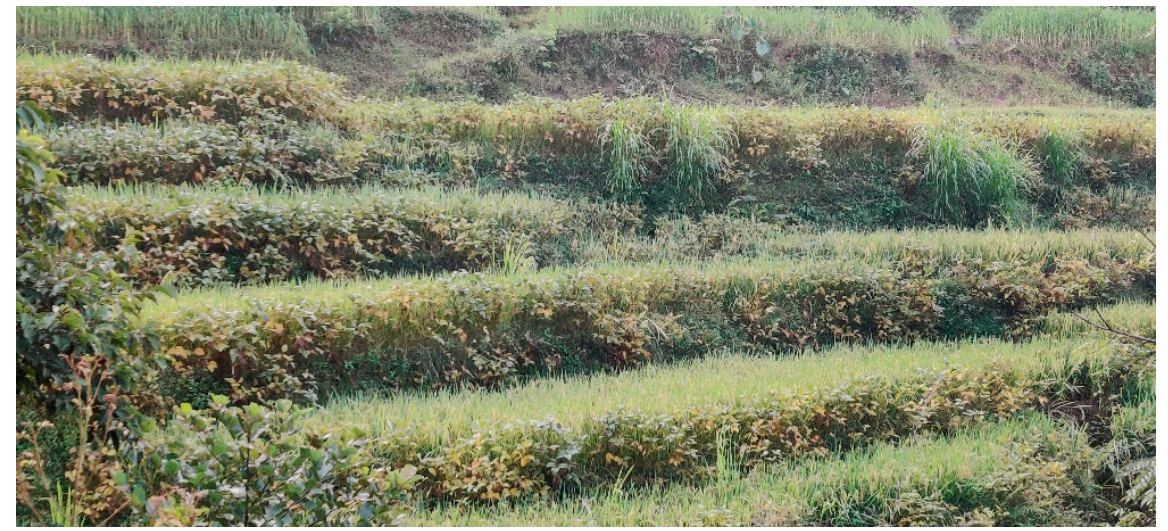

(a)

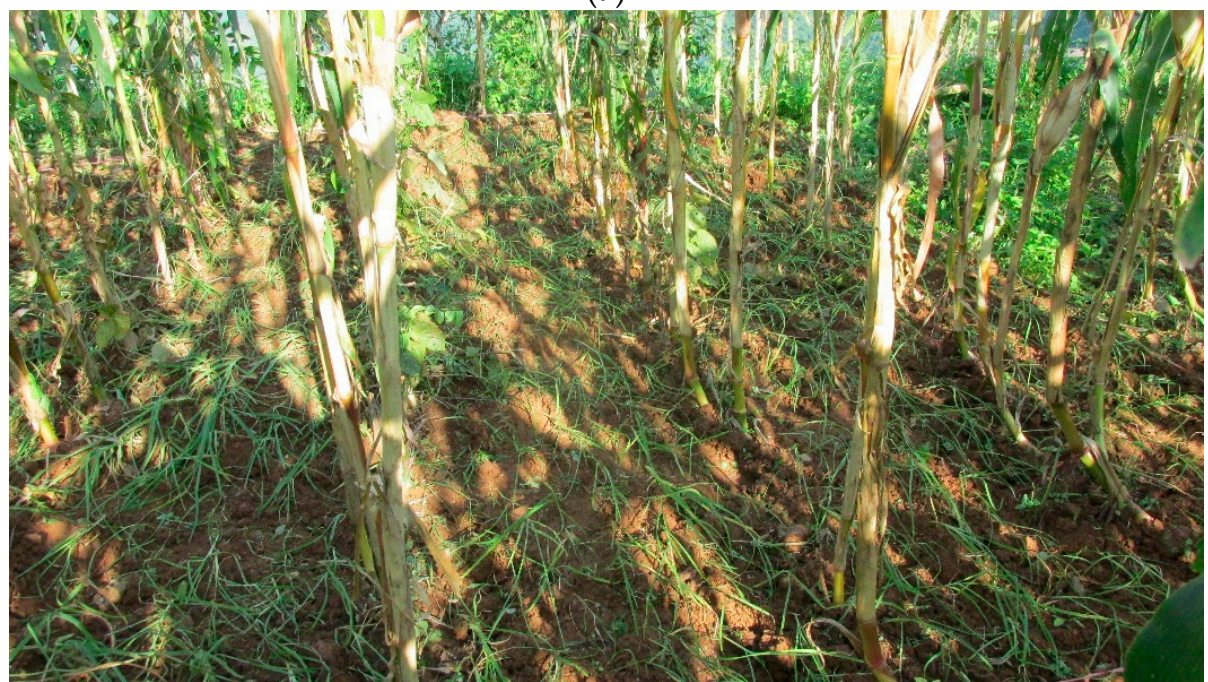

(b)

Figure 1. (a). Intercropping of blackgram and rice (Oryza sativa L.) on step farm in Nepal, (b). Corn intercropped with ginger (Zingiber officinale $\mathrm{L}$.).

In the case of weed management, intercropping reduces weed pressure and allows crops to proliferate. It works based on the principle of resource partitioning among co- 
occurring crop species with different resource acquisition strategies, allowing crops to use resources better and leaving less space, water, and nutrients to weeds [86]. Intercropping creates a situation with the increased availability of common limiting factors to the crop [87]. Resource partitioning is more likely to occur when functionally different crops are combined [88,89]. For example, cereals intercropped with legumes can improve nitrogen fixation, better weed control, and high yields [90-92]. Corre-Hellou et al. [93] reported pea (Pisum sativa L.)-barley (Hordeum vulgare L.) intercropping helped reduce weed biomass by threefold compared to pea monoculture. Similarly, Saucke and Ackermann [94] conclude that pea-alse flax (Camelina sativa L.) intercrop had a more significant suppressive effect on weeds than monocrops. Intercropping in drylands can help restore soil fertility and effective weed control. For instance, pearl millet in semi-arid and arid conditions intercropped with short-duration legume crops such as blackgram (Vigna mungo L.) and greengram (Vigna radiata L.) provides higher yield and reduced weed density and dry weight [95].

Furthermore, the spatial arrangement of the intercrops can significantly affect the yield and weed control. Alternate-row intercropping of soybean with lentil showed the highest yield, whereas the best weed control was reported with sunflower (2018), and buckwheat (2019) (Fagopyrum esculentum L.) while maintaining similar soybean yield [96]. Additionally, plant density of crop and intercrop can further affect weed suppression; for example, planting corn at a density of 9 plants $/ \mathrm{m}^{2}$ and simultaneously intercropping with cowpea at a density of 30 plants $/ \mathrm{m}^{2}$ leads to significant weed suppression when compared with monoculture corn [97].

Apart from the resource partitioning, intercropping may involve allelopathic interactions, which is environmentally friendly and provides economic weed control [98-100]. The mechanism of allelopathy involves both inhibitory and stimulatory relations among neighbor plants, directly affecting growth and development [101]. Among cultivated crops, sorghum species are extensively studied for their allelopathic potential and characterization of allelochemicals associated with weed suppression [102,103]. Several studies have indicated that intercropping sorghum with crops provides better weed control and higher yields than their monocrops [104-106]. Allelopathy is also associated with other field crops such as corn [107,108], oats (Avena sativa L.), pearl millet (Pennisetum glaucum L.), sesame (Sesamum indicum L.) [109], sunflower [104], and soybean [110]. All of the crops mentioned above showed weed suppression when intercropped with other cereals/legumes/oilseeds.

Striga spp. are among the notorious weed parasites, which can cause severe damage to crops. Intercropping is one of the effective methods to manage Striga for small-scale subsistence farmers. Oswald et al. [111] reported peanut (Arachis hypogaea L.), bean (Phaseolus vulgaris L.), yellow gram (Cicer arietinum L.), Bambara nut (Vigna subterranean L.), and soybean, when intercropped with corn, provides high productivity and stable Striga control. Furthermore, they indicated shading, higher humidity, and lower temperature under the intercrop canopies were mechanisms that caused a decline in Striga numbers. Allelopathic compounds from the Brassicaceae family are proven to be useful for the control of Orobanche spp. Fernandez-Aparicio et al. [112] showed that intercropping berseem clover (Trifolium alexandrinum L.) with pea, lentil, and chickling pea reduces the infestation of Orobanche crenata L. Similarly, witchweed (Striga hermonthica L.) haustorial development is inhibited by an aqueous solution eluted from silverleaf (Desmodium uncinatum L.). Furthermore, D. uncinatum, when intercropped with corn, showed a reduction in $S$. hermonthica infestation [113]. Thus, parasitic weeds can be managed by intercropping, and further investigation of the allelopathic exudates will help develop new bio-herbicides (e.g., Orobanche, Cimmino et al.) [114].

\subsection{Cover Crops}

Cover crops are crops planted between the growing seasons to improve soil health, reduce soil erosion, suppress weeds and other pests $[115,116]$. Cover crops suppress weed growth by multiple mechanisms such as competition for light, space, water, and 
nutrients [117]. After the termination of the crop, it forms a mulch layer on the soil surface, which is proven to reduce weed germination, emergence, and establishment [118-120]. Furthermore, cover crops and associated mulch have been shown to release allelochemicals, which further suppress weed growth [121]. A recent meta-analysis on 15 studies covering crop treatment in corn-soybean rotations showed that cover crop helps significantly reduce the weed biomass, but without changing the weed density. Moreover, to achieve a $75 \%$ reduction in weed biomass, it requires at least $5 \mathrm{mg} \mathrm{ha}^{-1}$ of the cover crop [122].

Cover crops require adequate soil water, moderate temperature, and good seedbed preparation for quick emergence and robust growth [123]. Therefore, the selection of the cover crops depends on field conditions, desirable outcome, and cost. For instance, 759 farmers were surveyed in North Carolina about the perception of cover crops, and $46 \%$ of them cited time and labor involved in cover crops as a reason not to adopt it [124]. Moreover, they reported $28.1 \%$ of farmers are using cover crops to control weeds. Additionally, Osipitan et al. [125] reported in a meta-analysis of 53 studies that grass cover species provide greater weed suppression compared to broadleaf; fall-sown cover crops provide higher weed suppression than spring-sown cover crops. Moreover, weed suppression increased by increasing the seedling rate of the cover crop from 1 to 3 . Thus, cover crop selection and management practices should be meticulously selected while considering cost and labor.

Common cover crops for weed control could be classified in four-group bases taxonomy: cereals, legumes, non-legumes, and brassicaceae plants [126]. One of the cereals, rye (Cereale secale L.), is most commonly used as a winter cover crop in soybean and corn as it provides reasonable weed control and yield [127]. Similarly, other commonly used cover crops viz white clover (Trifolium repens L.), annual ryegrass (Lolium multiflorum Lam. L.), crimson clover (Trifolium incarnatum L.), oilseed radish (Raphanus sativus L.), sunflower (Helianthus annuus L.), field pea, barley and hairy vetch (Vicia villosa L.) significantly suppress weeds as compared to monoculture crops [128-131]. Cover crops are planted either alone or in mixtures (to increase crop diversity). Mixture species with different characteristics create a single crop to perform various functions [132]. However, weed management studies have shown that mixture performs better when composed of highly competitive species since biomass is a major predictor of weed suppression [133-136]. Furthermore, Florence and McGuire [137] performed a meta-analysis on 27 studies and found that mixture and monoculture cover crops perform comparably equal in seven metrics (biomass, $\mathrm{N}$, weed, water, biology, yield, and stability). Time and method of cover crop termination can enhance, decrease or have no effect on weed establishment [138]. For example, Wallace et al. [120] reported that delaying cover crop termination can improve weed suppression through a higher accumulation of crop biomass. Cover crops can be terminated climatically, chemically, or mechanically; the appropriate method will depend on the farm management objective [139]. Thus, choice of cover crop, diversity, termination timing, and cover crops strategy can vastly affect weed suppression.

Cover crops are part of an integrated weed management practice, preventing and managing herbicide-resistant weeds (Table 1). For instance, Cholette et al. [140] showed that annual ryegrass alone or in combination with crimson clover leads to reduced density, biomass, and suppression of glyphosate-resistant Canada fleabane (Erigeron canadensis L.). However, in some cases, cover crops alone cannot control herbicide-resistant weeds. For example, hairy vetch and crimson clover residues provide early season suppression of glyphosate-resistant Palmer amaranth. However, the integration of herbicide mixtures that incorporate multiple sites of action with cover crops can help mitigate further selection of glyphosate resistance in Palmer amaranth (Amaranthus palmeri L.) [141]. Moreover, Bunchek et al. [142] concluded from their study that long-run intensified cover crops could be helpful to manage herbicide resistance since it will help reduce the herbicide selection pressure.

The diversity and size of the weed seedbank strongly influence the success of weed management practice. Cover crops can reduce weed seedbank by preventing propagule production, reducing seedling establishment, early/delay emergence [143]. Long-term 
use of the cover crop before cash crops can help to deplete weed seedbank. For instance, Nichols et al. [122] concluded from a 5-year study that long-term use of winter rye in the corn-soybean system has the potential to reduce the size of weed seedbanks compared to winter fallows. Moonen and Barberi et al. [144] reported similar results: after seven years, rye cover crop in corn resulted in a lower seedbank density when compared with the crop residue. However, some studies have noticed no apparent change in weed seedbank $[145,146]$. Hence, more research efforts are needed to understand the role of cover crops and weed seedbank.

Table 1. Crop diversification recommendations to control Palmer Amaranth, Blackgrass, and Rigid Ryegrass.

\begin{tabular}{|c|c|c|}
\hline \multicolumn{3}{|c|}{ Weed Species = Palmer Amaranth (Amaranthus palmeri) } \\
\hline Diversification Strategy * & Details & Reference \\
\hline Crop Rotation in cotton with corn & $\begin{array}{l}\text { Crop rotation of cotton and corn reduce the risk of developing } \\
\text { glyphosate resistance in Palmer amaranth by } \sim 50 \%\end{array}$ & [74] \\
\hline Cover crops for corn & $\begin{array}{l}\text { Hairy vetch and crimson clover provide early season } \\
\text { suppression for glyphosate-resistant Palmer Amaranth in corn }\end{array}$ & [141] \\
\hline Cover crops for cotton & $\begin{array}{l}\text { Austrian winterpea (Lathyrus hirsutus L.), cereal rye, crimson } \\
\text { clover, hairy vetch, oats, (Avena sativa L.), rapeseed, (Brassica } \\
\text { napus L.), and wheat can be used to reduce Palmer amaranth } \\
\text { emergence in cotton }\end{array}$ & {$[147,148]$} \\
\hline $\begin{array}{l}\text { Cover crop for glyphosate- and dicamba-tolerant } \\
\qquad \text { (GDT) soybean }\end{array}$ & $\begin{array}{c}\text { Hairy vetch and wheat were effective to control Palmer } \\
\text { amaranth. However, cover crop termination and herbicide } \\
\text { program should be taken into consideration for maximum } \\
\text { yield and highest weed control }\end{array}$ & [149] \\
\hline \multicolumn{3}{|c|}{ Weed Species = Blackgrass (Alopecurus myosuroides) } \\
\hline Cover crop for various crops & $\begin{array}{c}\text { Ryegrass as a cover crop can help to reduce the emergence of } \\
\text { blackgrass by } 17 \% \text {. It can be used as a cover crop in corn, } \\
\text { soybean, and winter-wheat }\end{array}$ & [150] \\
\hline Crop rotation of winter-annual and spring crops & $\begin{array}{c}\text { Five-year rotation with winter wheat, corn, summer barley, } \\
\text { winter oilseed rape, and winter wheat reduce blackgrass } \\
\text { densities by } 50 \% \text { as compared to winter wheat and winter } \\
\text { oilseed rape rotation }\end{array}$ & [151] \\
\hline \multicolumn{3}{|c|}{ Weed Species = Rigid Ryegrass (Lolium rigidum) } \\
\hline Crop rotation & $\begin{array}{l}\text { Oaten hay (Avena sativa), filed pea, wheat, and barley crop } \\
\text { rotation helps to deplete rigid ryegrass seedbank, reduce } \\
\text { in-crop weed infestation, and higher profitability }\end{array}$ & [152] \\
\hline Cover crop in corn & $\begin{array}{l}\text { Velvet bean (Mucuna pruriens (L.) DC. var. utilis) has } \\
\text { allelopathic potential and can help to reduce rigid ryegrass } \\
\text { biomass, height, and leaf number }\end{array}$ & [153] \\
\hline
\end{tabular}

* All diversification strategies were used in combination with a suitable herbicide program.

\section{Major Constraints to Adoption of Crop Diversification in Modern Agriculture}

A large-scale monoculture agriculture system has deeply entrenched across the world ensuing difficulty for any alternative production system such as diversified farming to flourish $[154,155]$. Reluctance among the commercial farmers in adopting crop diversification could be because of not prioritizing the importance of ecology or the lack of knowledge about diverse farming models and relevant scientific mechanisms governing their several advantages [34,156]. In the absence of proper knowledge and skills, it is evident for the farmers to be more doubtful of the economic success of relatively complex farming systems on a large-scale. In addition, the current agricultural technologies development is mostly centered towards sole-crop farming. For instance, plant breeding tools focusing on improving a few key traits have contributed to increased specialization and reduced genetic diversity [157]. Moreover, too much focus on plant improvement against biotic/ abiotic 
stresses is likely to limit the willingness of the farmers to adopt a diversified cropping system to develop crop resilience [40].

Although diversified farming uses agricultural inputs more judiciously and could be cheaper in the long run, small-scale farmers may struggle to establish a diverse agriculture farm as it requires more resources at the beginning. A case study on danish farmers revealed that, with the diversified cropping system, farmers experienced an increase in the types of farm activities, requiring broad knowledge, skills, equipment, manpower, and advisory services to run, and needing more years to return the initial investments [156]. Therefore, farmers with no other alternative income source are unlikely to take risk towards the diversified approach [154]. More naturally grown agricultural products seem to get a high price, and price risk is reduced with the diversification. However, farmers may experience difficulty in transportation and marketing for a small number of diverse products in a country such as the USA, where markets are confined to a limited number of large foodprocessing, distributing, and retailer firms [158].

Furthermore, agricultural policies are inclined towards industrialized and intensive agriculture, impeding the adoption of crop diversification. Most government incentives and subsidies focus mainly on increasing the production of certain agricultural commodities rather than implementing diversified farming $[40,159]$. In the United States, $89 \%$ of the total amount of subsidies between 1995 to 2005 went to producing five major crops [160]. In different geographies, local farmers following complex agricultural systems have better site-specific knowledge and experiences than anyone [161]. Not having proper policies and channels to disseminate farmers' knowledge to the extension workers and researchers also hinders the adoption of crop diversification. Inadequate legislation provisions to meet the needs of diversified farming are also reported by Aare et al. [156] in Denmark. More restrictions were found regarding the use of certain species or cultivars, thus discouraging diversification. On the other hand, current legislation in most countries allows organic farmers to meet the certification standards without following environmentally sustainable or diversified approaches [36], such as the conservation of weed biodiversity, including the Crop Wild Relatives $[162,163]$ with which the cultivated species can breeding providing more resistant hybrids available for use in agriculture, as the species of the genus Aegilops L. progenitor of cultivated wheat [164] or even Avena L. sp. pl. of cultivated oats.

\section{Crop Diversification in the Precision Agriculture Era}

As discussed in the previous section, the adoption of crop diversification is hindered to a greater extent because of its labor-intensive and time-consuming constraints, resulting in higher costs. The inadequate research further aggravates the condition to support farmers to enhance their knowledge and skills on diversified farming. However, with the advent of various precision agriculture (PA) tools, many problems associated with conventional methods of field examinations have been mitigated $[165,166]$, which could be helpful in the adoption of crop diversification. Such tools encompass advanced technologies such as Global Positioning Systems (GPS), Geographic Information Systems (GIS), remote sensing, artificial intelligence (AI), machine learning (ML), and simulation modeling [167].

GPS helps to provide the precise location with the help of satellites, and when embodied on other systems, it helps in the site-specific sampling or treatment applications based on location information [167]. On the other hand, GIS is a computer-based hardware and software system used to generate maps based on location data and the attributes of interest [168]. These two tools can be used to generate maps with different kinds of agronomic and other data to provide insights into the spatial and temporal variability of an area so that the plans on diversified cropping can be made accordingly to enhance productivity and profitability.

Remote sensing is a widely used tool in PA, which refers to data collection from a distance and is often based on the reflectance radiations from soil or plant [169]. Such radiations fall under a wide range of wavelengths which are assessed by using different 
hand-held sensors or sensors embodied in unmanned aerial vehicles (UAVs) $[170,171]$ and ground robotics [172].

The most widely used sensors and imaging techniques in different agricultural applications are multispectral and hyperspectral cameras, thermal cameras, light detection and ranging sensors (LiDAR), artificial vision sensors, etc. [173]. The raw data obtained with these techniques often need to be processed, and different indices (For example, NDVI) and models are developed using ML, AI, and regression techniques [166,174]. These models can estimate a wide range of agronomic traits and other physio-biological variables. The technique has been used for crop monitoring and high throughput phenotyping $[17,167,175]$ and estimating various agronomic traits such as yield $[176,177]$, canopy dimensions [178], leaf nutrient concentrations [174,179], and biomass [180]. Moreover, they have also been used in disease identification and quantification [181-183], identifying water-related stress [184], scouting weeds and insects [185,186], etc. These techniques can surely help researchers, at least in part, to take data quickly from any complex, diversified farming system conveniently and more economically. Moreover, when farmers employ these tools in their diversified farms, they can monitor their fields more often and identify the required treatments with high accuracy.

Additionally, precision agriculture in a diversified farm will reduce the cost by allowing farmers to use agriculture inputs according to the exact need of the grown crop. For instance, practices such as selective fertilizer applications and selective weed control ensure the optimum application of the treatment, thus preventing their overuse or underuse. Site-specific weed management using autonomous spraying UAVs based on remote-weed mapping has already been developed [187]. Variable-rate fertilizer application techniques based on nutrient maps of the field have also been developed [188]. These techniques would improve the agriculture input efficiency, reduce the losses to the environment, and reduce greenhouse gas emissions [189]. Therefore, besides optimizing the use of agriculture inputs and reducing time and labor requirements, precision agriculture tools also help to attain the principle of sustainable, diversified farming.

Recent progress has shown that PA technologies are more applicable, accurate, and efficient than ever [190]. Even though the current use of PA tools is employed only in highly capitalized larger farms in developed countries, the use of PA in diversified farming could result in sustainable and resilient cropping systems with enhanced productivity. So, future precision agriculture technology development works should focus on diversified farming and, if possible, small-scale farmers by creating more affordable tools.

\section{Conclusions}

Despite high yields and low input cost, the modern monoculture system relies heavily on chemicals for weed control generating human health, environmental and ecological concerns. Herbicide-resistant weeds, increasing health issues associated with agricultural chemicals, water and soil pollution are among the major negative impacts of modern agriculture. New and innovative strategies for sustainable weed management are imperative for sustainable weed management before irreversible damage to humans and the environment. The best strategy for developing a resilient and sustainable production system is adopting diversified farming with ecological weed management options. However, farmers are reluctant to adopt a diversified cropping system because of the requirement of varying skill sets and higher initial investment. Efforts must be taken by both government agencies and the private sectors to promote diversified farming among the commercial and small-scale farmers for developing sustainable farming systems in the future.

Author Contributions: Conceptualization, G.S., S.S., S.K. and T.-M.T.; Investigation, G.S., S.S., S.K. and T.-M.T.; Resources, G.S., S.S., S.K. and T.-M.T.; Writing-Original Draft Preparation, G.S., S.S. and S.K.; Writing-Review and Editing, G.S., S.S., S.K. and T.-M.T.; Visualization, G.S., S.S., S.K. and T.-M.T.; Funding Acquisition, T.-M.T. All authors have read and agreed to the published version of the manuscript. 
Funding: Funding for this project was provided by the Mississippi Agricultural and Forestry Experiment Station, and is based upon work that is supported by the National Institute of Food and Agriculture, U.S. Department of Agriculture, Hatch project under accession number 230100.

Institutional Review Board Statement: Not applicable.

Informed Consent Statement: Not applicable.

Data Availability Statement: Not applicable.

Conflicts of Interest: The authors declare no conflict of interest.

\section{References}

1. WSSA GLOSSARY. Available online: https:/ /wssa.net/wssa/wssa-glossary/ (accessed on 2 May 2021).

2. Harlan, J.R.; de Wet, J.M.J. Some Thoughts about Weeds. Econ. Bot. 1965, 19, 16-24. [CrossRef]

3. Cousens, R. A Simple Model Relating Yield Loss to Weed Density. Ann. Appl. Biol. 1985, 107, 239-252. [CrossRef]

4. Chauhan, B.S. Grand Challenges in Weed Management. Front. Agron. 2020, 1. [CrossRef]

5. Fahad, S.; Hussain, S.; Chauhan, B.S.; Saud, S.; Wu, C.; Hassan, S.; Tanveer, M.; Jan, A.; Huang, J. Weed Growth and Crop Yield Loss in Wheat as Influenced by Row Spacing and Weed Emergence Times. Crop Prot. 2015, 71, 101-108. [CrossRef]

6. Oerke, E.-C. Crop Losses to Pests. J. Agric. Sci. 2006, 144, 31-43. [CrossRef]

7. Loux, M.M.; Doohan, D.; Dobbels, A.F.; Johnson, W.G.; Young, B.G.; Legleiter, T.R.; Hager, A. Weed Control Guide for Ohio; University of Illinois: Champaign, IL, USA, 2017; pp. 1-2.

8. Soltani, N.; Dille, J.A.; Burke, I.C.; Everman, W.J.; VanGessel, M.J.; Davis, V.M.; Sikkema, P.H. Perspectives on Potential Soybean Yield Losses from Weeds in North America. Weed Technol. 2017, 31, 148-154. [CrossRef]

9. Soltani, N.; Dille, J.A.; Burke, I.C.; Everman, W.J.; VanGessel, M.J.; Davis, V.M.; Sikkema, P.H. Potential Corn Yield Losses from Weeds in North America. Weed Technol. 2016, 30, 979-984. [CrossRef]

10. Llewellyn, R.S.; Ronning, D.; Ouzman, J.; Walker, S.; Mayfield, A.; Clarke, M. Impact of Weeds on Australian Grain Production: The Cost of Weeds to Australian Grain Growers and the Adoption of Weed Management and Tillage Practices; Report for Grains Research \& Development Corporation: Canberra, Australia, 2016.

11. Gharde, Y.; Singh, P.K.; Dubey, R.P.; Gupta, P.K. Assessment of Yield and Economic Losses in Agriculture Due to Weeds in India. Crop Prot. 2018, 107, 12-18. [CrossRef]

12. Mesterházy, Á.; Oláh, J.; Popp, J. Losses in the Grain Supply Chain: Causes and Solutions. Sustainability 2020, 12, 2342. [CrossRef]

13. Ramesh, K.; Matloob, A.; Aslam, F.; Florentine, S.K.; Chauhan, B.S. Weeds in a Changing Climate: Vulnerabilities, Consequences, and Implications for Future Weed Management. Front. Plant Sci. 2017, 8, 95. [CrossRef]

14. Tirado, R.; Englande, A.J.; Promakasikorn, L.; Novotny, V. Use of Agrochemicals in Thailand and Its Consequences for the Environment. Available online: http:/ / www.greenpeace.to/publications/GPSEA_agrochemical-use-in-thailand.pdf (accessed on 28 March 2021).

15. Gianessi, L.P. The Increasing Importance of Herbicides in Worldwide Crop Production: The Increasing Importance of Herbicides. Pest Manag. Sci. 2013, 69, 1099-1105. [CrossRef] [PubMed]

16. Pariona, A. Top Pesticide Using Countries. Available online: https://www.worldatlas.com/articles/top-pesticide-consumingcountries-of-the-world.html (accessed on 28 March 2021).

17. Oca, A.M.; Arreola, L.; Flores, A.; Sanchez, J.; Flores, G. Low-Cost Multispectral Imaging System for Crop Monitoring; IEEE: Dallas, TX, USA, 2018.

18. Available online: http:/ / www.weedscience.org/Home.aspx (accessed on 28 March 2021).

19. Egan, J.F.; Mortensen, D.A. Quantifying Vapor Drift of Dicamba Herbicides Applied to Soybean. Environ. Toxicol. Chem. 2012, 31, 1023-1031. [CrossRef] [PubMed]

20. Perrino, E.V.; Calabrese, G. Endangered Segetal Species in Southern Italy: Distribution, Conservation Status, Trends, Actions and Ethnobotanical Notes. Genet. Resour. Crop Evol. 2018, 65, 2107-2134. [CrossRef]

21. Shrestha, S.; Sharma, G.; Burgos, N.R.; Tseng, T.-M. Response of Weedy Rice (Oryza spp.) Germplasm from Arkansas to Glyphosate, Glufosinate, and Flumioxazin. Weed Sci. 2019, 67, 303-310. [CrossRef]

22. Yu, Q.; Cairns, A.; Powles, S. Glyphosate, Paraquat and ACCase Multiple Herbicide Resistance Evolved in a Lolium Rigidum Biotype. Planta 2007, 225, 499-513. [CrossRef]

23. Owen, M.J.; Walsh, M.J.; Llewellyn, R.S.; Powles, S.B. Widespread Occurrence of Multiple Herbicide Resistance in Western Australian Annual Ryegrass (Lolium Rigidum) Populations. Aust. J. Agric. Res. 2007, 58, 711. [CrossRef]

24. Tseng, T.-M.; Shrestha, S.; McCurdy, J.D.; Wilson, E.; Sharma, G. Target-Site Mutation and Fitness Cost of Acetolactate Synthase Inhibitor-Resistant Annual Bluegrass. HortScience 2019, 54, 701-705. [CrossRef]

25. Yuan, J.S.; Tranel, P.J.; Stewart, C.N., Jr. Non-Target-Site Herbicide Resistance: A Family Business. Trends Plant Sci. 2007, 12, 6-13. [CrossRef]

26. Duke, S.O. Why Have No New Herbicide Modes of Action Appeared in Recent Years? Pest Manag. Sci. 2012, 68, 505-512. [CrossRef]

27. Egan, J.F.; Barlow, K.M.; Mortensen, D.A. A Meta-Analysis on the Effects of 2,4-D and Dicamba Drift on Soybean and Cotton. Weed Sci. 2014, 62, 193-206. [CrossRef] 
28. Suarez Cadavid, L.A. Proximal and Remote Sensing for Early Detection and Assessment of Herbicide Drift Damage on Cotton Crops; University of Southern Queensland: Toowoomba, Australia, 2018.

29. Zhang, J.; Huang, Y.; Reddy, K.N.; Wang, B. Assessing Crop Damage from Dicamba on Non-dicamba-tolerant Soybean by Hyperspectral Imaging through Machine Learning. Pest Manag. Sci. 2019, 75, 3260-3272. [CrossRef]

30. Udeigwe, T.K.; Teboh, J.M.; Eze, P.N.; Stietiya, M.H.; Kumar, V.; Hendrix, J.; Mascagni, H.J., Jr.; Ying, T.; Kandakji, T. Implications of Leading Crop Production Practices on Environmental Quality and Human Health. J. Environ. Manag. 2015, 151, 267-279. [CrossRef] [PubMed]

31. Gilliom, R.J. Pesticides in U.S. Streams and Groundwater. Environ. Sci. Technol. 2007, 41, 3408-3414. [CrossRef] [PubMed]

32. Van Bruggen, A.H.C.; He, M.M.; Shin, K.; Mai, V.; Jeong, K.C.; Finckh, M.R.; Morris, J.G., Jr. Environmental and Health Effects of the Herbicide Glyphosate. Sci. Total Environ. 2018, 616-617, 255-268. [CrossRef]

33. Sterling, T.D.; Arundel, A.V. Health Effects of Phenoxy Herbicides: A Review. Scand. J. Work Environ. Health 1986, 12, 161-173. [CrossRef] [PubMed]

34. Liebman, M.; Staver, C.P. Crop Diversification for Weed Management. In Ecological Management of Agricultural Weeds; Cambridge University Press: Cambridge, UK, 2001; pp. 322-374.

35. Smith, R.G.; Gross, K.L. Assembly of Weed Communities along a Crop Diversity Gradient. J. Appl. Ecol. 2007, 44, 1046-1056. [CrossRef]

36. Kremen, C.; Miles, A. Ecosystem Services in Biologically Diversified versus Conventional Farming Systems: Benefits, Externalities, and Trade-Offs. Ecol. Soc. 2012, 1. [CrossRef]

37. Liebman, M.; Dyck, E. Crop Rotation and Intercropping Strategies for Weed Management. Ecol. Appl. 1993, 3, 92-122. [CrossRef]

38. Hufnagel, J.; Reckling, M.; Ewert, F. Diverse Approaches to Crop Diversification in Agricultural Research. A Review. Agron. Sustain. Dev. 2020, 40. [CrossRef]

39. Bommarco, R.; Kleijn, D.; Potts, S.G. Ecological Intensification: Harnessing Ecosystem Services for Food Security. Trends Ecol. Evol. 2013, 28, 230-238. [CrossRef]

40. Lin, B.B. Resilience in Agriculture through Crop Diversification: Adaptive Management for Environmental Change. Bioscience 2011, 61, 183-193. [CrossRef]

41. Meynard, J.M.; Messéan, A.; Charlier, A.; Charrier, F.; Farès, M.; Le Bail, M.; Savini, I. Crop Diversification: Obstacles and Levers; INRA: Paris, France, 2013.

42. Blaix, C.; Moonen, A.C.; Dostatny, D.F.; Izquierdo, J.; Le Corff, J.; Morrison, J.; Von Redwitz, C.; Schumacher, M.; Westerman, P.R. Quantification of Regulating Ecosystem Services Provided by Weeds in Annual Cropping Systems Using a Systematic Map Approach. Weed Res. 2018, 58, 151-164. [CrossRef]

43. Capinera, J.L. Relationships between Insect Pests and Weeds: An Evolutionary Perspective. Weed Sci. 2005, 53, 892-901. [CrossRef]

44. Bretagnolle, V.; Gaba, S. Weeds for Bees? A Review. Agron. Sustain. Dev. 2015, 35, 891-909. [CrossRef]

45. Smith, B.M.; Aebischer, N.J.; Ewald, J.; Moreby, S.; Potter, C.; Holland, J.M. The Potential of Arable Weeds to Reverse Invertebrate Declines and Associated Ecosystem Services in Cereal Crops. Front. Sustain. Food Syst. 2020, 3. [CrossRef]

46. Mouritsen, O.G. Those Tasty Weeds. J. Appl. Phycol. 2017, 29, 2159-2164. [CrossRef]

47. Amato-Lourenco, L.F.; Ranieri, G.R.; de Oliveira Souza, V.C.; Junior, F.B.; Saldiva, P.H.N.; Mauad, T. Edible Weeds: Are Urban Environments Fit for Foraging? Sci. Total Environ. 2020, 698, 133967. [CrossRef]

48. Varvel, G.E. Crop Rotation and Nitrogen Effects on Normalized Grain Yields in a Long-term Study. Agron. J. 2000, 92, 938-941. [CrossRef]

49. Bowles, T.M.; Mooshammer, M.; Socolar, Y.; Calderón, F.; Cavigelli, M.A.; Culman, S.W.; Deen, W.; Drury, C.F.; Garcia y Garcia, A.; Gaudin, A.C.M.; et al. Long-Term Evidence Shows That Crop-Rotation Diversification Increases Agricultural Resilience to Adverse Growing Conditions in North America. One Earth 2020, 2, 284-293. [CrossRef]

50. Zhao, J.; Yang, Y.; Zhang, K.; Jeong, J.; Zeng, Z.; Zang, H. Does Crop Rotation Yield More in China? A Meta-Analysis. Field Crops Res. 2020, 24, 107659. [CrossRef]

51. Weisberger, D.; Nichols, V.; Liebman, M. Does Diversifying Crop Rotations Suppress Weeds? A Meta-Analysis. PLoS ONE 2019, 14, e0219847. [CrossRef] [PubMed]

52. Anderson, R.L. Managing Weeds with a Dualistic Approach of Prevention and Control. A Review. Agron. Sustain. Dev. 2007, 27, 13-18. [CrossRef]

53. Liebman, M.; Miller, Z.J.; Williams, C.L.; Westerman, P.R.; Dixon, P.M.; Heggenstaller, A.; Sundberg, D.N. Fates of Setaria Faberi and Abutilon Theophrasti Seeds in Three Crop Rotation Systems. Weed Res. 2014, 54, 293-306. [CrossRef]

54. Simić, M.; Spasojević, I.; Kovacević, D.; Brankov, M.; Dragicević, V. Crop Rotation Influence on Annual and Perennial Weed Control and Maize Productivity. Rom Agric Res. 2016, 33, 125-133.

55. Satorre, E.H.; de la Fuente, E.B.; Mas, M.T.; Suárez, S.A.; Kruk, B.C.; Guglielmini, A.C.; Verdú, A.M.C. Crop Rotation Effects on Weed Communities of Soybean (Glycine max L. Merr.) Agricultural Fields of the Flat Inland Pampa. Crop Prot. 2020, 130, 105068. [CrossRef]

56. Simić, M.S.; Dragičević, V.; Chachalis, D.; Dolijanović, Ž.; Brankov, M. Integrated Weed Management in Long-Term Maize Cultivation. Zemdirbyste 2020, 107, 33-40. [CrossRef]

57. Mishra, J.S.; Kumar, R.; Kumar, R.; Rao, K.K.; Bhatt, B.P. Weed Density and Species Composition in Rice-Based Cropping Systems as Affected by Tillage and Crop Rotation. Ind. J. Weed Sci. 2019, 51, 116. [CrossRef] 
58. Liebman, M.; Nichols, V.A. Cropping System Redesign for Improved Weed Management: A Modeling Approach Illustrated with Giant Ragweed (Ambrosia Trifida). Agronomy 2020, 10, 262. [CrossRef]

59. Schönhart, M.; Schmid, E.; Schneider, U.A. CropRota-A Crop Rotation Model to Support Integrated Land Use Assessments. Eur. J. Agron. 2011, 34, 263-277. [CrossRef]

60. Dury, J.; Schaller, N.; Garcia, F.; Reynaud, A.; Bergez, J.E. Models to Support Cropping Plan and Crop Rotation Decisions. A Review. Agron. Sustain. Dev. 2012, 32, 567-580. [CrossRef]

61. Dogliotti, S.; Rossing, W.A.H.; van Ittersum, M.K. Rotat, a Tool for Systematically Generating Crop Rotations. Eur. J. Agron. 2003, 19, 239-250. [CrossRef]

62. Colbach, N.; Colas, F.; Pointurier, O.; Queyrel, W.; Villerd, J. A Methodology for Multi-Objective Cropping System Design Based on Simulations. Application to Weed Management. Eur. J. Agron. 2017, 87, 59-73. [CrossRef]

63. Haring, S.C.; Flessner, M.L. Improving Soil Seed Bank Management: Improving Soil Seed Bank Management. Pest Manag. Sci. 2018, 74, 2412-2418. [CrossRef] [PubMed]

64. Anderson, R. An Ecological Approach to Strengthen Weed Management in the Semiarid Great Plains. In Adv. Agron; Elsevier: Amsterdam, The Netherlands, 2003; pp. 33-62.

65. Anderson, R.L. Sequencing Crops to Minimize Selection Pressure for Weeds in the Central Great Plains1. Weed Technol. 2004, 18, 157-164. [CrossRef]

66. Kumar, A.; Choudhary, T.; Das, S.; Meena, S.K. Weed Seed Bank: Impacts and Management for Future Crop Production. In Agronomic Crops; Springer: Singapore, 2019; pp. 207-223.

67. Leibman, M.; Davis, A.S. Managing Weed in Organic Farming Systems: An Ecological Approach; Francis, C., Ed.; American Society of Agronomy: Madison, WI, USA, 2009; pp. 173-196.

68. Cardina, J.; Herms, C.P.; Doohan, D.J. Crop Rotation and Tillage System Effects on Weed Seedbanks. Weed Sci. 2002, 50, 448-460. [CrossRef]

69. Westerman, P.R.; Liebman, M.; Menalled, F.D.; Heggenstaller, A.H.; Hartzler, R.G.; Dixon, P.M. Are Many Little Hammers Effective? Velvetleaf (Abutilon Theophrasti) Population Dynamics in Two-and Four-Year Crop Rotation Systems. Weed Sci. 2005, 53, 382-392. [CrossRef]

70. Oswald, A.; Ransom, J.K. Striga Control and Improved Farm Productivity Using Crop Rotation. Crop Prot. 2001, 20, 113-120. [CrossRef]

71. Samaké, O.; Stomph, T.J.; Kropff, M.J.; Smaling, E.M.A. Integrated Pearl Millet Management in the Sahel: Effects of Legume Rotation and Fallow Management on Productivity and Striga Hermonthica Infestation. Plant Soil 2006, 286, 245-257. [CrossRef]

72. Hayat, S.; Wang, K.; Liu, B.; Wang, Y.; Chen, F.; Li, P.; Hayat, K.; Ma, Y. A Two-Year Simulated Crop Rotation Confirmed the Differential Infestation of Broomrape Species in China Is Associated with Crop-Based Biostimulants. Agronomy 2019, 10, 18. [CrossRef]

73. Norsworthy, J.K.; Ward, S.M.; Shaw, D.R.; Llewellyn, R.S.; Nichols, R.L.; Webster, T.M.; Bradley, K.W.; Frisvold, G.; Powles, S.B.; Burgos, N.R.; et al. Reducing the Risks of Herbicide Resistance: Best Management Practices and Recommendations. Weed Sci. 2012, 60, 31-62. [CrossRef]

74. Neve, P.; Norsworthy, J.K.; Smith, K.L.; Zelaya, I.A. Modeling Glyphosate Resistance Management Strategies for Palmer Amaranth (Amaranthus palmeri) in Cotton. Weed Technol. 2011, 25, 335-343. [CrossRef]

75. Lutman, P.J.W.; Moss, S.R.; Cook, S.; Welham, S.J. A Review of the Effects of Crop Agronomy on the Management of ALopecurus Myosuroides. Weed Res. 2013, 53, 299-313. [CrossRef]

76. Moss, S.R.; Hull, R. Quantifying the Benefits of Spring Cropping for Control of Alopecurus Myosuroides Black-Grass. Asp. Appl. Biol. 2012, 117, 1-6.

77. Ulber, L.; Rissel, D. Farmers' Perspective on Herbicide-Resistant Weeds and Application of Resistance Management Strategies: Results from a German Survey. Pest Manag. Sci. 2018, 74, 2335-2345. [CrossRef]

78. Beckie, H.J.; Harker, K.N. Our Top 10 Herbicide-Resistant Weed Management Practices. Pest Manag. Sci. 2017, 73, 1045-1052. [CrossRef]

79. Goplen, J.J.; Coulter, J.A.; Sheaffer, C.C.; Becker, R.L.; Breitenbach, F.R.; Behnken, L.M.; Gunsolus, J.L. Economic Performance of Crop Rotations in the Presence of Herbicide-Resistant Giant Ragweed. Agron. J. 2018, 110, 260-268. [CrossRef]

80. Goplen, J.J.; Sheaffer, C.C.; Becker, R.L.; Coulter, J.A.; Breitenbach, F.R.; Behnken, L.M.; Johnson, G.A.; Gunsolus, J.L. Seedbank Depletion and Emergence Patterns of Giant Ragweed (Ambrosia trifida) in Minnesota Cropping Systems. Weed Sci. 2017, 65, 52-60. [CrossRef]

81. Simmonds, N.W.; Vandermeer, J. The Ecology of Intercropping. J. Appl. Ecol. 1989, 26, 1107. [CrossRef]

82. Ngwira, A.R.; Aune, J.B.; Mkwinda, S. On-Farm Evaluation of Yield and Economic Benefit of Short-Term Maize Legume Intercropping Systems under Conservation Agriculture in Malawi. Field Crops Res. 2012, 132, 149-157. [CrossRef]

83. Brooker, R.W.; Bennett, A.E.; Cong, W.-F.; Daniell, T.J.; George, T.S.; Hallett, P.D.; Hawes, C.; Iannetta, P.P.M.; Jones, H.G.; Karley, A.J.; et al. Improving Intercropping: A Synthesis of Research in Agronomy, Plant Physiology and Ecology. New Phytol. 2015, 206, 107-117. [CrossRef]

84. Lithourgidis, A.S.; Dordas, C.A.; Damalas, C.A.; Vlachostergios, D. Annual Intercrops: An Alternative Pathway for Sustainable Agriculture. Aust. J. Crop Sci. 2011, 5, 396. 
85. Smith, J.; Pearce, B.D.; Wolfe, M.S. Reconciling Productivity with Protection of the Environment: Is Temperate Agroforestry the Answer? Renew. Agric. Food Syst. 2013, 28, 80-92. [CrossRef]

86. Pakeman, R.J.; Brooker, R.W.; Karley, A.J.; Newton, A.C.; Mitchell, C.; Hewison, R.L.; Schöb, C. 473 Increased Crop Diversity Reduces the Functional Space Available for Weeds. Weed Res. 2019, 60, 121-131. [CrossRef]

87. Marschner, P. (Ed.) Mineral Nutrition of Higher Plants, 3rd ed.; Academic Press: Waltham, MA, USA, 2012.

88. Bybee-Finley, K.A.; Mirsky, S.B.; Ryan, M.R. Crop Biomass Not Species Richness Drives Weed Suppression in Warm-Season Annual Grass-Legume Intercrops in the Northeast. Weed Sci. 2017, 65, 669-680. [CrossRef]

89. Stefan, L.; Engbersen, N.; Schöb, C. Crop-Weed Relationships Are Context-Dependent and Cannot Fully Explain the Positive Effects of Intercropping on Yield. Ecol. Appl. 2021, e2311. [CrossRef]

90. Verret, V.; Gardarin, A.; Pelzer, E.; Médiène, S.; Makowski, D.; Valantin-Morison, M. Can Legume Companion Plants Control Weeds without Decreasing Crop Yield? A Meta-Analysis. Field Crops Res. 2017, 204, 158-168. [CrossRef]

91. Rodriguez, C.; Carlsson, G.; Englund, J.-E.; Flöhr, A.; Pelzer, E.; Jeuffroy, M.-H.; Makowski, D.; Jensen, E.S. Grain Legume-Cereal Intercropping Enhances the Use of Soil-Derived and Biologically Fixed Nitrogen in Temperate Agroecosystems. A Meta-Analysis. Eur. J. Agron. 2020, 118, 126077. [CrossRef]

92. Weed 427 Suppression Greatly Increased by Plant Diversity in Intensively Managed Grasslands: A Continental-Scale 428 Experiment. J. Appl. Ecol. 2017, 55, 852-862.

93. Corre-Hellou, G.; Dibet, A.; Hauggaard-Nielsen, H.; Crozat, Y.; Gooding, M.; Ambus, P.; Dahlmann, C.; von Fragstein, P.; Pristeri, A.; Monti, M.; et al. The Competitive Ability of Pea-Barley Intercrops against Weeds and the Interactions with Crop Productivity and Soil N Availability. Field Crops Res. 2011, 122, 264-272. [CrossRef]

94. Saucke, H.; Ackermann, K. Weed Suppression in Mixed Cropped Grain Peas and False Flax (Camelina sativa). Weed Res. 2006, 6, 453-461. [CrossRef]

95. Mathukia, R.K.; Mathukia, P.R.; Polara, A.M. Intercropping and Weed Management in Pearlmillet (Pennisetum glaucum) under Rainfed Condition. Agric. Sci. Dig. Res. J. 2015, 35, 138. [CrossRef]

96. Cheriere, T.; Lorin, M.; Corre-Hellou, G. Species Choice and Spatial Arrangement in Soybean-Based Intercropping: Levers That Drive Yield and Weed Control. Field Crops Res. 2020, 256, 107923. [CrossRef]

97. Jamshidi, K.; Yousefi, A.R.; Oveisi, M. Effect of Cowpea (Vigna unguiculata) Intercropping on Weed Biomass and Maize (Zea Mays) Yield. N. Z. J. Crop Hortic. Sci. 2013, 41, 180-188. [CrossRef]

98. Farooq, M.; Jabran, K.; Cheema, Z.A.; Wahid, A.; Siddique, K.H.M. The Role of Allelopathy in Agricultural Pest Management. Pest Manag. Sci. 2011, 67, 493-506. [CrossRef] [PubMed]

99. Tesio, F.; Ferrero, A. Allelopathy, a Chance for Sustainable Weed Management. Int. J. Sustain. Dev. World Ecol. 2010, 17, 377-389. [CrossRef]

100. Makoi, J.H.; Ndakidemi, P.A. Allelopathy as Protectant, Defence and Growth Stimulants in Legume Cereal Mixed Culture Systems. N. Z. J. Crop Hortic. Sci. 2012, 40, 161-186. [CrossRef]

101. Arowosegbe, S.; Afolayan, A.J. Assessment of Allelopathic Properties of Aloe Ferox Mill. on Turnip, Beetroot and Carrot. Biol. Res. 2012, 45, 363-368. [CrossRef]

102. Głąb, L.; Sowiński, J.; Bough, R.; Dayan, F.E. Allelopathic Potential of Sorghum (Sorghum Bicolor (L.) Moench) in Weed Control: A Comprehensive Review. Adv. Agron 2017, 145, 43-95.

103. Sowiński, J.; Dayan, F.E.; Głąb, L.; Adamczewska-Sowińska, K. Sorghum Allelopathy for Sustainable Weed Management. In Progress in Biological Control; Springer International Publishing: Cham, Switzerland, 2020; pp. 263-288.

104. Kandhro, M.N.; Tunio, S.; Rajpar, I.; Chachar, Q. Allelopathic Impact of Sorghum and Sunflower Intercropping on Weed Management and Yield Enhancement in Cotton. Sarhad J. Agric. 2014, 30, 312-318.

105. Mahmood, A.; Cheema, Z.A.; Mushtaq, M.N.; Farooq, M. Maize-Sorghum Intercropping Systems for Purple Nutsedge Management. Arch. Acker Pflanzenbau Bodenkd. 2013, 59, 1279-1288. [CrossRef]

106. dos Santos, R.C.; de Morais Guerra Ferraz, G.; de Albuquerque, M.B.; de Lima, L.M.; de Albuquerque Melo Filho, P.; de Rezende Ramos, A. Temporal Expression of the Sor1 Gene and Inhibitory Effects of Sorghum Bicolor L. Moench on Three Weed Species. Acta Bot. Brasilica 2014, 28, 361-366. [CrossRef]

107. Dhungana, S.K.; Kim, I.-D.; Adhikari, B.; Kim, J.-H.; Shin, D.-H. Reduced Germination and Seedling Vigor of Weeds with Root Extracts of Maize and Soybean, and the Mechanism Defined as Allelopathic. J. Crop Sci. Biotechnol. 2019, 22, 11-16. [CrossRef]

108. Jabran, K. Sorghum Allelopathy for Weed Control. In Manipulation of Allelopathic Crops for Weed Control; Springer International Publishing: Cham, Switzerland, 2017; pp. 65-75.

109. Blaise, D.; Manikandan, A.; Verma, P.; Nalayini, P.; Chakraborty, M.; Kranthi, K.R. Allelopathic Intercrops and Its Mulch as an Integrated Weed Management Strategy for Rainfed Bt-Transgenic Cotton Hybrids. Crop Prot. 2020, 135, 105214. [CrossRef]

110. Iqbal, J.; Cheema, Z.A.; An, M. Intercropping of Field Crops in Cotton for the Management of Purple Nutsedge (Cyperus rotundus L.). Plant Soil 2007, 300, 163-171. [CrossRef]

111. Oswald, A.; Ransom, J.K.; Kroschel, J.; Sauerborn, J. Intercropping Controls Striga in Maize Based Farming Systems. Crop Prot. 2002, 21, 367-374. [CrossRef]

112. Fernández-Aparicio, M.; Emeran, A.A.; Rubiales, D. Inter-Cropping with Berseem Clover (Trifolium alexandrinum) Reduces Infection by Orobanche Crenata in Legumes. Crop Prot. 2010, 29, 867-871. [CrossRef] 
113. Khan, Z.R.; Hassanali, A.; Overholt, W.; Khamis, T.M.; Hooper, A.M.; Pickett, J.A.; Wadhams, L.J.; Woodcock, C.M. Control of Witchweed Striga Hermonthica by Intercropping with Desmodium Spp., and the Mechanism Defined as Allelopathic. J. Chem. Ecol. 2002, 28, 1871-1885. [CrossRef]

114. Cimmino, A.; Fernández-Aparicio, M.; Avolio, F.; Yoneyama, K.; Rubiales, D.; Evidente, A. Ryecyanatines A and B and Ryecarbonitrilines A and B, Substituted Cyanatophenol, Cyanatobenzo [1,3] Dioxole, and Benzo [1, 3] Dioxolecarbonitriles from Rye (Secale cereale L.) Root Exudates: Novel Metabolites with Allelopathic Activity on Orobanche Seed Germination and Radicle Growth. Phytochemistry 2015, 109, 57-65.

115. Blanco-Canqui, H.; Shaver, T.M.; Lindquist, J.L.; Shapiro, C.A.; Elmore, R.W.; Francis, C.A.; Hergert, G.W. Cover Crops and Ecosystem Services: Insights from Studies in Temperate Soils. Agron. J. 2015, 107, 2449-2474. [CrossRef]

116. Baraibar, B.; Hunter, M.C.; Schipanski, M.E.; Hamilton, A.; Mortensen, D.A. Weed Suppression in Cover Crop Monocultures and Mixtures. Weed Sci. 2018, 66, 121-133. [CrossRef]

117. Thorup-Kristensen, K.; Magid, J.; Jensen, L.S. Catch Crops and Green Manures as Biological Tools in Nitrogen Management in Temperate Zones. In Adv. Agron; Elsevier: Amsterdam, The Netherlands, 2003; pp. 227-302.

118. Teasdale, J.R.; Abdul-Baki, A.A.; Bong Park, Y. Sweet Corn Production and Efficiency of Nitrogen Use in High Cover Crop Residue. Agron. Sustain. Dev. 2008, 28, 559-565. [CrossRef]

119. Peachey, R.E.; William, R.D.; Mallory-Smith, C. Effect of No-till or Conventional Planting and Cover Crops Residues on Weed Emergence in Vegetable Row Crop. Weed Technol. 2004, 18, 1023-1030. [CrossRef]

120. Wallace, J.; Williams, A.; Liebert, J.; Ackroyd, V.; Vann, R.; Curran, W.; Keene, C.; VanGessel, M.; Ryan, M.; Mirsky, S. Cover Crop-Based, Organic Rotational No-till Corn and Soybean Production Systems in the Mid-Atlantic United States. Agriculture 2017, 7, 34. [CrossRef]

121. Singh, H.P.; Batish, D.R.; Kohli, R.K. Allelopathic Interactions and Allelochemicals: New Possibilities for Sustainable Weed Management. CRC Crit. Rev. Plant Sci. 2003, 22, 239-311. [CrossRef]

122. Nichols, V.; Martinez-Feria, R.; Weisberger, D.; Carlson, S.; Basso, B.; Basche, A. Cover Crops and Weed Suppression in the US Midwest: A Meta-analysis and Modeling Study. Agric. Environ. Lett. 2020, 5, 20022. [CrossRef]

123. Brust, J.; Claupein, W.; Gerhards, R. Growth and Weed Suppression Ability of Common and New Cover Crops in Germany. Crop Prot. 2014, 63, 1-8. [CrossRef]

124. Myers, R.; Watts, C. Progress and Perspectives with Cover Crops: Interpreting Three Years of Farmer Surveys on Cover Crops. J. Soil Water Conserv. 2015, 70, 125A-129A. [CrossRef]

125. Osipitan, O.A.; Dille, J.A.; Assefa, Y.; Radicetti, E.; Ayeni, A.; Knezevic, S.Z. Impact of Cover Crop Management on Level of Weed Suppression: A Meta-Analysis. Crop Sci. 2019, 59, 833-842. [CrossRef]

126. Mennan, H.; Jabran, K.; Zandstra, B.H.; Pala, F. Non-Chemical Weed Management in Vegetables by Using Cover Crops: A Review. Agronomy 2020, 10, 257. [CrossRef]

127. DeVore, J.D.; Norsworthy, J.K.; Brye, K.R. Influence of Deep Tillage, a Rye Cover Crop, and Various Soybean Production Systems on Palmer Amaranth Emergence in Soybean. Weed Technol. 2013, 27, 263-270. [CrossRef]

128. Kadziene, G.; Suproniene, S.; Auskalniene, O.; Pranaitiene, S.; Svegzda, P.; Versuliene, A.; Ceseviciene, J.; Janusauskaite, D.; Feiza, V. Tillage and Cover Crop Influence on Weed Pressure and Fusarium Infection in Spring Cereals. Crop Prot. 2020, 127, 104966. [CrossRef]

129. Weber, J.; Kunz, C.; Peteinatos, G.; Zikeli, S.; Gerhards, R. Weed Control Using Conventional Tillage, Reduced Tillage, No-Tillage, and Cover Crops in Organic Soybean. Agriculture 2017, 7, 43. [CrossRef]

130. Brooker, A.P.; Renner, K.A.; Basso, B. Interseeding Cover Crops in Corn: Establishment, Biomass, and Competitiveness in On-farm Trials. Agron. J. 2020, 112, 3733-3743. [CrossRef]

131. Büchi, L.; Wendling, M.; Amossé, C.; Jeangros, B.; Charles, R. Cover Crops to Secure Weed Control Strategies in a Maize Crop with Reduced Tillage. Field Crops Res. 2020, 247, 107583. [CrossRef]

132. Finney, D.M.; Murrell, E.G.; White, C.M.; Baraibar, B.; Barbercheck, M.E.; Bradley, B.A.; Cornelisse, S.; Hunter, M.C.; Kaye, J.P.; Mortensen, D.A.; et al. Ecosystem Services and Disservices Are Bundled in Simple and Diverse Cover Cropping Systems. Agric. Environ. Lett. 2017, 2, 170033. [CrossRef]

133. Finney, D.M.; White, C.M.; Kaye, J.P. Biomass Production and Carbon/Nitrogen Ratio Influence Ecosystem Services from Cover Crop Mixtures. Agron. J. 2016, 108, 39-52. [CrossRef]

134. Smith, R.G.; Atwood, L.W.; Pollnac, F.W.; Warren, N.D. Cover-Crop Species as Distinct Biotic Filters in Weed Community Assembly. Weed Sci. 2015, 63, 282-295. [CrossRef]

135. MacLaren, C.; Swanepoel, P.; Bennett, J.; Wright, J.; Dehnen-Schmutz, K. Cover Crop Biomass Production Is More Important than Diversity for Weed Suppression. Crop Sci. 2019, 59, 733-748. [CrossRef]

136. Schappert, A.; Schumacher, M.; Gerhards, R. Weed Control Ability of Single Sown Cover Crops Compared to Species Mixtures. Agronomy 2019, 9, 294. [CrossRef]

137. Florence, A.M.; McGuire, A.M. Do Diverse Cover Crop Mixtures Perform Better than Monocultures? A Systematic Review. Agron. J. 2020, 112, 3513-3534. [CrossRef]

138. Rosario-Lebron, A.; Leslie, A.W.; Yurchak, V.L.; Chen, G.; Hooks, C.R.R. Can Winter Cover Crop Termination Practices Impact Weed Suppression, Soil Moisture, and Yield in No-till Soybean [Glycine max (L.) Merr.]? Crop Prot. 2019, 116, 132-141. [CrossRef] 
139. Wortman, S.E.; Francis, C.A.; Bernards, M.A.; Blankenship, E.E.; Lindquist, J.L. Mechanical Termination of Diverse Cover Crop Mixtures for Improved Weed Suppression in Organic Cropping Systems. Weed Sci. 2013, 61, 162-170. [CrossRef]

140. Cholette, T.B.; Soltani, N.; Hooker, D.C.; Robinson, D.E.; Sikkema, P.H. Suppression of Glyphosate-Resistant Canada Fleabane (Conyza canadensis) in Corn with Cover Crops Seeded after Wheat Harvest the Previous Year. Weed Technol. 2018, 32, 244-250. [CrossRef]

141. Wiggins, M.S.; McClure, M.A.; Hayes, R.M.; Steckel, L.E. Integrating Cover Crops and POST Herbicides for Glyphosate-Resistant Palmer Amaranth (Amaranthus palmeri) Control in Corn. Weed Technol. 2015, 29, 412-418. [CrossRef]

142. Bunchek, J.M.; Wallace, J.M.; Curran, W.S.; Mortensen, D.A.; VanGessel, M.J.; Scott, B.A. Alternative Performance Targets for Integrating Cover Crops as a Proactive Herbicide-Resistance Management Tool. Weed Sci. 2020, 68, 534-544. [CrossRef]

143. Gallandt, E.R. How Can We Target the Weed Seedbank? Weed Sci. 2006, 54, 588-596. [CrossRef]

144. Moonen, A.C.; Barberi, P. Size and Composition of the Weed Seedbank after 7 Years of Different Cover-Crop-Maize Management Systems. Weed Res. 2004, 44, 163-177. [CrossRef]

145. Buchanan, A.L.; Kolb, L.N.; Hooks, C.R.R. Can Winter Cover Crops Influence Weed Density and Diversity in a Reduced Tillage Vegetable System? Crop Prot. 2016, 90, 9-16. [CrossRef]

146. Alonso-Ayuso, M.; Gabriel, J.L.; García-González, I.; Del Monte, J.P.; Quemada, M. Weed Density and Diversity in a Long-Term Cover Crop Experiment Background. Crop Prot. 2018, 112, 103-111. [CrossRef]

147. Palhano, M.G.; Norsworthy, J.K.; Barber, T. Cover Crops Suppression of Palmer Amaranth (Amaranthus palmeri) in Cotton. Weed Technol. 2018, 32, 60-65. [CrossRef]

148. Wiggins, M.S.; Hayes, R.M.; Steckel, L.E. Evaluating Cover Crops and Herbicides for Glyphosate-Resistant Palmer Amaranth (Amaranthus palmeri) Control in Cotton. Weed Technol. 2016, 30, 415-422. [CrossRef]

149. Montgomery, G.B.; McClure, A.T.; Hayes, R.M.; Walker, F.R.; Senseman, S.A.; Steckel, L.E. Dicamba-Tolerant Soybean Combined Cover Crop to Control Palmer Amaranth. Weed Technol. 2018, 32, 109-115. [CrossRef]

150. Cordeau, S.; Wayman, S.; Reibel, C.; Strbik, F.; Chauvel, B.; Guillemin, J.-P. Effects of Drought on Weed Emergence and Growth Vary with the Seed Burial Depth and Presence of a Cover Crop: Weed Emergence in No-till Systems. Weed Biol. Manag. 2018, 18, 12-25. [CrossRef]

151. Zeller, A.; Kaiser, Y.; Gerhards, R. Suppressing Alopecurus Myosuroides Huds. In Rotations of Winter-Annual and Spring Crops. Agriculture 2018, 8, 91. [CrossRef]

152. Kleemann, S.G.L.; Preston, C.; Gill, G.S. Influence of Management on Long-Term Seedbank Dynamics of Rigid Ryegrass (Lolium rigidum) in Cropping Systems of Southern Australia. Weed Sci. 2016, 64, 303-311. [CrossRef]

153. Travlos, I.; Roussis, I.; Roditis, C.; Semini, C.; Rouvali, L.; Stasinopoulou, P.; Chimona, N.; Vlassopoulou, C.; Bilalis, D. Allelopathic Potential of Velvet Bean against Rigid Ryegrass. Not. Bot. Horti Agrobot. Cluj Napoca 2018, 46, 173-176. [CrossRef]

154. Iles, A.; Marsh, R. Nurturing Diversified Farming Systems in Industrialized Countries: How Public Policy Can Contribute. Ecol. Soc. 2012, 17, 42 .

155. Kremen, C.; Iles, A.; Bacon, C. Diversified Farming Systems: An Agroecological, Systems-Based Alternative to Modern Industrial Agriculture. Ecol. Soc. 2012, 17. [CrossRef]

156. Aare, A.K.; Egmose, J.; Lund, S.; Hauggaard-Nielsen, H. Opportunities and Barriers in Diversified Farming and the Use of Agroecological Principles in the Global North-The Experiences of Danish Biodynamic Farmers. Agroecol. Sustain. Food Syst. 2020, 45, 1-27. [CrossRef]

157. Heal, G.; Walker, B.; Levin, S.; Arrow, K.; Dasgupta, P.; Daily, G.; Ehrlich, P.; Maler, K.-G.; Kautsky, N.; Lubchenco, J.; et al. Genetic Diversity and Interdependent Crop Choices in Agriculture. Res. Energy Econ. 2004, 26, 175-184. [CrossRef]

158. Hendrickson, M.; Heffernan, W. Concentration of Agricultural Markets; Department of Rural Sociology, University of Missouri: Columbia, MO, USA, 2007.

159. Buttel, F.H. Sustaining the Unsustainable: Agro-Food Systems and Environment in the Modern World; In Handbook of Rural Studies; Sage Pub.: London, UK, 2006; pp. 213-229.

160. Boody, G.; Vondracek, B.; Andow, D.A.; Krinke, M.; Westra, J.; Zimmerman, J.; Welle, P. Multifunctional Agriculture in the United States. Bioscience 2005, 55, 27. [CrossRef]

161. Thurston, H.D. Slash/Mulch Systems: Sustainable Methods for Tropical Agriculture; Westview: Boulder, CO, USA, 1997.

162. Maxted, N.; Kell, S. Establishment of a Global Network for the in-Situ Conservation of Crop Wild Relatives: Status and Needs; FAO Commission on Genetic Resources for Food and Agriculture: Rome, Italy, 2009.

163. Hajjar, R.; Hodgkin, T. The Use of Wild Relatives in Crop Improvement: A Survey of Developments over the Last 20 Years. Euphytica 2007, 156, 1-13. [CrossRef]

164. Perrino, E.V.; Wagensommer, R.P.; Medagli, P. The Genus Aegilops (Poaceae) in Italy: Taxonomy, Geographical Distribution, Ecology, Vulnerability and Conservation. SYST BIODIVERS 2014, 12, 331-349. [CrossRef]

165. Du, Q.; Chang, N.-B.; Yang, C.; Srilakshmi, K.R. Combination of Multispectral Remote Sensing, Variable Rate Technology and Environmental Modeling for Citrus Pest Management. J. Environ. Manag. 2008, 86, 14-26. [CrossRef] [PubMed]

166. Ampatzidis, Y.; Partel, V.; Meyering, B.; Albrecht, U. Citrus Rootstock Evaluation Utilizing UAV-Based Remote Sensing and Artificial Intelligence. Comput. Electron. Agric. 2019, 164, 104900. [CrossRef]

167. Kent Shannon, D.; Clay, D.E.; Sudduth, K.A. An Introduction to Precision Agriculture. In Precision Agriculture Basics; American Society of Agronomy and Soil Science Society of America: Madison, WI, USA, 2018; pp. 1-12. 
168. Brase, T. Basics of a Geographic Information System. In Precision Agriculture Basics; American Society of Agronomy and Soil Science Society of America: Madison, WI, USA, 2018; pp. 37-62.

169. Mulla, D.J. Twenty-Five Years of Remote Sensing in Precision Agriculture: Key Advances and Remaining Knowledge Gaps. Biosyst. Eng. 2013, 114, 358-371. [CrossRef]

170. Rokhmana, C.A. The Potential of UAV-Based Remote Sensing for Supporting Precision Agriculture in Indonesia. Procedia Environ. Sci. 2015, 24, 245-253. [CrossRef]

171. Sapkota, B.; Singh, V.; Cope, D.; Valasek, J.; Bagavathiannan, M. Mapping and Estimating Weeds in Cotton Using Unmanned Aerial Systems-Borne Imagery. Agri. Eng. 2020, 2, 350-366. [CrossRef]

172. Reynolds, D.; Baret, F.; Welcker, C.; Bostrom, A.; Ball, J.; Cellini, F.; Lorence, A.; Chawade, A.; Khafif, M.; Noshita, K.; et al. What Is Cost-Efficient Phenotyping? Optimizing Costs for Different Scenarios. Plant Sci. 2019, 282, 14-22. [CrossRef]

173. Narvaez, F.Y.; Reina, G.; Torres-Torriti, M.; Kantor, G.; Cheein, F.A. A Survey of Ranging and Imaging Techniques for Precision Agriculture Phenotyping. IEEE/ASME Trans. Mechatron 2017, 22, 2428-2439. [CrossRef]

174. Osco, L.P.; Ramos, A.P.M.; Faita Pinheiro, M.M.; Moriya, É.A.S.; Imai, N.N.; Estrabis, N.; Ianczyk, F.; de Araújo, F.F.; Liesenberg, V.; Jorge, L.A.d.C.; et al. A Machine Learning Framework to Predict Nutrient Content in Valencia-Orange Leaf Hyperspectral Measurements. Remote Sens. 2020, 12, 906. [CrossRef]

175. Xu, R.; Li, C.; Paterson, A.H. Multispectral Imaging and Unmanned Aerial Systems for Cotton Plant Phenotyping. PLoS ONE 2019, 14, e0205083. [CrossRef] [PubMed]

176. Hassan, M.A.; Yang, M.; Rasheed, A.; Yang, G.; Reynolds, M.; Xia, X.; Xiao, Y.; He, Z. A Rapid Monitoring of NDVI across the Wheat Growth Cycle for Grain Yield Prediction Using a Multi-Spectral UAV Platform. Plant Sci. 2019, 282, 95-103. [CrossRef] [PubMed]

177. Mirasi, A.; Mahmoudi, A.; Navid, H.; Valizadeh Kamran, K.; Asoodar, M.A. Evaluation of Sum-NDVI Values to Estimate Wheat Grain Yields Using Multi-Temporal Landsat OLI Data. Geocarto Int. 2019, 1-16. [CrossRef]

178. Matese, A.; Di Gennaro, S.F.; Berton, A. Assessment of a Canopy Height Model (CHM) in a Vineyard Using UAV-Based Multispectral Imaging. Int. J. Remote Sens. 2017, 38, 2150-2160. [CrossRef]

179. Costa, L.; Kunwar, S.; Ampatzidis, Y.; Albrecht, U. Estimating Leaf Nutrient Concentrations in Citrus Trees Using UAV Imagery and Gradient Boosting Decision Tree Regression. 2021; Unpublished Work.

180. Shendryk, Y.; Sofonia, J.; Garrard, R.; Rist, Y.; Skocaj, D.; Thorburn, P. Fine-Scale Prediction of Biomass and Leaf Nitrogen Content in Sugarcane Using UAV LiDAR and Multispectral Imaging. ITC J. 2020, 92, 102177. [CrossRef]

181. Cui, D.; Zhang, Q.; Li, M.; Hartman, G.L.; Zhao, Y. Image Processing Methods for Quantitatively Detecting Soybean Rust from Multispectral Images. Biosyst. Eng. 2010, 107, 186-193. [CrossRef]

182. Garcia-Ruiz, F.; Sankaran, S.; Maja, J.M.; Lee, W.S.; Rasmussen, J.; Ehsani, R. Comparison of Two Aerial Imaging Platforms for Identification of Huanglongbing-Infected Citrus Trees. Comput. Electron. Agric. 2013, 91, 106-115. [CrossRef]

183. Qin, Z.; Zhang, M. Detection of Rice Sheath Blight for In-Season Disease Management Using Multispectral Remote Sensing. ITC J. 2005, 7, 115-128. [CrossRef]

184. Ondimu, S.; Murase, H. Water Stress Detection in Sunagoke Moss (Rhacomitrium canescens) Using Combined Thermal Infrared and Visible Light Imaging Techniques. Biosyst. Eng. 2008, 100, 4-13. [CrossRef]

185. Partel, V.; Nunes, L.; Stansly, P.; Ampatzidis, Y. Automated Vision-Based System for Monitoring Asian Citrus Psyllid in Orchards Utilizing Artificial Intelligence. Comput. Electron. Agric. 2019, 162, 328-336. [CrossRef]

186. Li, L.; Fan, Y.; Huang, X.; Tian, L. Real-Time UAV Weed Scout for Selective Weed Control by Adaptive Robust Control and Machine Learning Algorithm; American Society of Agricultural and Biological Engineers: St. Joseph, MI, USA, 2016.

187. Laursen, M.; Jørgensen, R.; Midtiby, H.; Jensen, K.; Christiansen, M.; Giselsson, T.; Mortensen, A.; Jensen, P. Dicotyledon Weed Quantification Algorithm for Selective Herbicide Application in Maize Crops. Sensors 2016, 16, 1848. [CrossRef] [PubMed]

188. Ferguson, R.B.; Luck, J.D.; Stevens, R. Developing Prescriptive Soil Nutrient Maps. In Practical Mathematics for Precision Farming; American Society of Agronomy and Soil Science Society of America: Madison, WI, USA, 2018; pp. 149-166.

189. Finger, R.; Swinton, S.M.; El Benni, N.; Walter, A. Precision Farming at the Nexus of Agricultural Production and the Environment. Annu. Rev. Resour. Econ. 2019, 11,313-335. [CrossRef]

190. Weersink, A.; Fraser, E.; Pannell, D.; Duncan, E.; Rotz, S. Opportunities and Challenges for Big Data in Agricultural and Environmental Analysis. Annu. Rev. Resour. Econ. 2018, 10, 19-37. [CrossRef] 